\title{
Bicarbonate Absorption Stimulates Active Calcium Absorption in the Rat Proximal Tubule
}

\author{
Karol Bomsztyk and Mihail B. Calalb \\ Division of Nephrology, University of Washington, Seattle, Washington 98195
}

\begin{abstract}
To evaluate the effect of luminal bicarbonate on calcium reabsorption, rat proximal tubules were perfused in vivo. Perfusion solution contained mannitol to reduce water flux to zero. Total Ca concentration was measured by atomic absorption spectrometry, $\mathrm{Ca}$ ion concentration in the tubule lumen $\left(\mathrm{Ca}_{\mathrm{L}}{ }^{2+}\right)$ and the peritubular capillary $\left(\mathrm{Ca}_{\mathrm{P}}{ }^{2+}\right)$, and luminal $\mathrm{pH}\left(\mathrm{pH}_{\mathrm{L}}\right)$ with ion-selective microelectrodes and transepithelial voltage $\left(V_{\mathrm{TE}}\right)$ with conventional microelectrodes.

When tubules were perfused with buffer-free Cl-containing solution, net $\mathrm{Ca}$ absorption $\left(J_{\mathrm{C}_{\mathrm{a}}}\right)$ averaged $3.33 \mathrm{pmol} / \mathrm{min}$. Even though $V_{\text {TE }}$ was $1.64 \mathrm{mV}$ lumen-positive, $\mathrm{Ca}_{\mathrm{L}}{ }^{2+}, 1.05$ $\mathrm{mM}$, did not fall below the concentration in the capillary blood, $1.07 \mathrm{mM}$. When $27 \mathrm{mM}$ of $\mathrm{Cl}$ was replaced with $\mathrm{HCO}_{3}$, there was luminal fluid acidification. Despite a decrease in $V_{T E}$ and $\mathrm{Ca}_{\mathrm{L}}{ }^{2+}, J_{\mathrm{Ca}}$ increased to $7.13 \mathrm{pmol} / \mathrm{min}$, indicating that the enhanced $J_{\mathrm{Ca}}$ could not be accounted for by the reduced electrochemical gradient, $\Delta \tilde{C}_{\mathrm{Ca}}$. When acetazolamide or an analogue of amiloride was added to the $\mathrm{HCO}_{3}$ solution, $J_{\mathrm{Ca}}$ was not different from the buffer-free solution, suggesting that $\mathrm{HCO}_{3}$ stimulated $J_{C_{a}}$ may be linked to acidification. To further test this hypothesis, we used $27 \mathrm{mM}$ Hepes as the luminal buffer. With Hepes there was luminal fluid acidification and $J_{\mathrm{Ca}}$ was not different from the buffer-free solution but $\Delta \tilde{C}_{\mathrm{Ca}_{a}}$ was significantly reduced, indicating enhanced active calcium transport.

We conclude from the results of the present study that $\mathrm{HCO}_{3}$ stimulates active $\mathrm{Ca}$ absorption, a process that may be linked to acidification-mediated $\mathrm{HCO}_{3}$ absorption.
\end{abstract}

\section{Introduction}

Bicarbonate administration is known to decrease urinary calcium excretion in acidotic (1-3) and nonacidotic states (4). Sutton et al. (2) showed that infusion of $\mathrm{HCO}_{3}$ to dogs did not enhance proximal $\mathrm{Ca}$ reabsorption and concluded that the decreased urinary $\mathrm{Ca}$ excretion was the result of a direct $\mathrm{HCO}_{3}$ effect to increase $\mathrm{Ca}$ absorption beyond the late proximal tubule. In that study $\mathrm{HCO}_{3}$ administration was associated with decreased plasma ultrafilterable $\mathrm{Ca}$ and decreased proximal fluid reabsorption. Both of these effects would alter proximal $\mathrm{Ca}$ transport and could mask any direct effects of luminal $\mathrm{HCO}_{3}$.

In the rat proximal tubule, Ullrich et al. (5) also did not find a direct effect of $\mathrm{HCO}_{3}$ on active $\mathrm{Ca}$ transport. However,

Received for publication 5 June 1987 and in revised form 22 September 1987.

J. Clin. Invest.

(c) The American Society for Clinical Investigation, Inc.

0021-9738/88/05/1455/07 \$2.00

Volume 81, May 1988, 1455-1461 in that study direct measurements of transepithelial voltage $\left(V_{\mathrm{TE}}\right)$ and calcium ion concentration in the lumen and capillary blood were not made, rendering the interpretation of the data difficult. With the recent introduction of $\mathrm{Ca}^{2+}$ ion selective microelectrodes direct in situ measurements are now possible (6).

The present study was designed to reexamine the effects of luminal $\mathrm{HCO}_{3}$ on proximal $\mathrm{Ca}$ transport, while keeping transepithelial water flow near zero and accounting for changes in the transepithelial electrochemical driving forces by in situ measurements of transepithelial voltage and calcium ion concentration. The results show that, in the absence of net transepithelial water flow, luminal $\mathrm{HCO}_{3}$ stimulates calcium absorption by an active transport process that appears to be linked to tubule fluid acidification.

\section{Methods}

Male Sprague-Dawley rats (Bantin \& Kingman, Freemont, CA) weighing $250-300 \mathrm{~g}$ were anesthetized by intraperitoneal injection of 5-sec-butyl-2-ethyl thiobarbituric acid (Inactin, Byk-Gulden, Konstanz, Federal Republic of Germany) (100 mg/kg body weight) and were prepared for in vivo micropuncture and microperfusion as previously described $(6,7)$. A continuous intravenous infusion of solution containing $140 \mathrm{mM} \mathrm{NaCl}$ and $4.0 \mathrm{mM} \mathrm{KCl}$ at a rate of $0.1 \mathrm{ml} / \mathrm{min}$ per kg body weight was administered and arterial blood pressure was monitored throughout the experiment. The surface of the kidney was bathed with solution that contained (in $\mathrm{mM}$ ) Na $140, \mathrm{Cl} 117, \mathrm{HCO}_{3}$

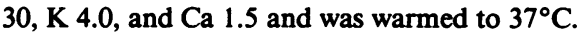

Calcium transport. Composition of perfusion fluids is given in Table I. To identify proximal tubules having four or more surface segments, a solution containing $0.5 \mathrm{~g} /$ liter Brilliant Blue FCF dye (Pfaltz \& Bauer, Inc., Stamford, CT) was injected into a tubule segment by means of a micropipette (3-5 $\mu$ m o.d.) and was observed as it flowed downstream. A microperfusion pipette (5-7 $\mu \mathrm{m})$ was attached to a pump (K. Effenberger, Munich, FRG) and was inserted into the second most proximal tubule identified. The perfusion rate was set at $18 \mathrm{nl} / \mathrm{min}$. The most proximal surface segment was filled with bone wax injected from a micropipette (10-12 $\mu \mathrm{m}$ o.d.) attached to a hydraulic microdrive (model 3-0590, Trent Wells, South Gate, CA). Enough pressure was applied to inject a wax column up to the perfusion site but not beyond it. The wax pipette was then withdrawn, permitting the glomerular filtrate to escape through the hole in the tubule wall proximal to the wax block. Contamination of perfusion fluid by glomerular filtrate was thus avoided. After 1-2 min a micropipette (8-10 $\mu$ o.d.) containing colored (Sudan black) mineral oil was inserted into one of the visible segments (three to four segments distal to the perfusion site). Oil was injected at this site and then held in this place distal to the puncture by collecting all luminal fluid for 5-6 min. At the end of the collection period the collection pipette was quickly removed from the tubule, and a small amount of oil was drawn into the pipette to prevent evaporation of the collected fluid. The volume of each collected fluid sample was measured using a precalibrated constant-bore glass tubing $(0.1 \mathrm{~mm}$ i.d.). A measured volume of the sample was then transferred for $\left[{ }^{14} \mathrm{C}\right]$ inulin radioactivity measurements. After the collection was completed, the perfusion pipette was removed and a latex compound (General Biological, Chicago, IL) was injected 
Table I. Composition of Perfusion Solutions

\begin{tabular}{lccccc}
\hline & \multicolumn{5}{c}{ Solution } \\
\cline { 2 - 6 } Solute & I & II & III & IV & V \\
\hline & & & $m M$ & & \\
$\mathrm{NaCl}$ & 142 & 115 & 115 & 115 & 115 \\
$\mathrm{KCl}$ & 4.0 & 4.0 & 4.0 & 4.0 & 4.0 \\
$\mathrm{CaCl}_{2}$ & 1.5 & 1.5 & 1.5 & 1.5 & 1.5 \\
$\mathrm{MgCl}_{2}$ & 1.0 & 1.0 & 1.0 & 1.0 & 1.0 \\
$\mathrm{Na}_{2} \mathrm{HPO}_{4}$ & 1.0 & 1.0 & 1.0 & 1.0 & 1.0 \\
$\mathrm{NaHCO}_{3}$ & & 27 & 27 & 27 & \\
$\mathrm{Na} \mathrm{Hepes}$ & & & & & 27 \\
$\mathrm{ATZ}$ & & & 1.0 & & \\
$\mathrm{MIA}$ & & & & 0.01 & \\
Mannitol & 30 & 26 & 32 & 26 & 28 \\
& & & & & \\
\hline
\end{tabular}

All solutions contained $0.5 \mathrm{~g}$ /liter brilliant blue FCF dye and $10 \mu \mathrm{Ci}$ / $\mathrm{ml}\left[{ }^{14} \mathrm{C}\right]$ inulin.

into the tubule from the collection site. When all collections were completed the kidney was removed and digested in $6 \mathrm{M} \mathrm{HCl}$ at $25^{\circ} \mathrm{C}$ for $24 \mathrm{~h}$. The latex casts of the tubules were teased free from the unfilled tubules and the lengths of the perfused segments were measured.

The in vivo perfusion rate averaged $18.0 \pm 0.3 \mathrm{nl} / \mathrm{min}(n=150)$ and was determined in each tubule from the relation $V_{\mathrm{o}}=V_{\mathrm{L}}[I n]_{\mathrm{L}} /[\mathrm{In}]_{\mathrm{o}}$, where $V_{\mathrm{L}}$ is the collection rate of tubule fluid at the end the perfused segment, and $[I n]$ is the $\left[{ }^{14} \mathrm{C}\right]$ inulin radioactivity in the collected (L) and the initial $(0)$ perfusion fluid. The rate of water transport $\left(J_{\mathrm{v}}\right)$ was calculated as the difference between $V_{\mathrm{o}}$ and $V_{\mathrm{L}}$. Sufficient concentration of mannitol was added to each solution to reduce $J_{\mathrm{v}}$ near zero $(6-8)$. Net transport of calcium $\left(J_{\mathrm{Ca}}\right)$ or sodium $\left(J_{\mathrm{Na}}\right)$ was calculated as $J_{\mathrm{i}}=V_{\mathrm{o}}[i]_{\mathrm{o}}-V_{\mathrm{L}}[i]_{\mathrm{L}}$, where $[i]_{\mathrm{o}}$ and $[i]_{\mathrm{L}}$ are the total calcium or sodium concentration in the perfusion and collection fluids. Total calcium and sodium concentration in perfusion and collection fluids were measured by flameless atomic absorption spectrometry (model 655/951, Instrumentation Laboratory, Inc., Lexington, MA) (6, 7). Perfusion and collection fluids were diluted 1:2,000 with deionized water in 1.5-ml Eppendorf tubes, and $10 \mu \mathrm{l}$ of the diluted samples (Eppendorf ultramicropipettor) was used to measure total calcium and $1 \mu \mathrm{l}$ to measure total sodium concentration.

Voltage, calcium activity, and pH measurements. Measurements of $V_{\mathrm{TE}}, a \mathrm{Ca}_{\mathrm{L}}$, and $\mathrm{pH}_{\mathrm{L}}$ were made in a different group of animals from the group used for ion transport studies. A modification of the perfusion technique used for ion transport experiments was used in which two perfusion pipettes were positioned in the same tubule segment. One pipette had a solution containing $140 \mathrm{mM} \mathrm{NaCl}$ and $4.0 \mathrm{mM} \mathrm{KCl}$ and contained no dye. The second pipette contained one of the perfusion solutions in Table I. When fluid was being pumped from the second pipette, the perfusion segments appeared green; when fluid was being pumped from the first pipette, the green fluid was cleared from the tubule. The transepithelial voltage ( $\left.V_{\mathrm{TE}}\right)$, luminal calcium activity $\left(a \mathrm{Ca}_{\mathrm{L}}\right)$, and $\mathrm{pH}\left(\mathrm{pH}_{\mathrm{L}}\right)$ were measured by means of microelectrodes placed in the last visible segment of the perfused tubule (three to four surface segments distal to the pump). The intraluminal position of the microelectrodes was assured by switching from one solution to the other and observing the colored fluid appear in or wash out of the tubule at the same time that a change was observed in the microelectrode voltage reading. In most of the experiments, measurements of $V_{\mathrm{TE}}$ and $a \mathrm{Ca}_{\mathrm{L}}$ were taken simultaneously in the same tubule segment. $\mathrm{pH}$ measurements were made in a different group of animals without measuring $\mathrm{V}_{\mathrm{TE}}$.

The microelectrodes used for transepithelial voltage $\left(V_{\mathrm{TE}}\right)$ measurements had beveled tips (3-5 $\mu \mathrm{m}$ o.d.) and were filled with $3 \mathrm{M} \mathrm{KCl}$ in
$2 \%$ agar. These electrodes have relatively low resistances $(<1 \mathrm{M} \Omega)$ and, with the perfusates used, have negligible tip potentials (8). The electrode was connected to one of the two channels of a high-impedance electrometer (model FD-223, W-P Instruments, New Haven, CT) via a $\mathrm{Ag}-\mathrm{AgCl}$ wire. The reference side of the circuit was connected through a polyethylene tube filled with $3 \mathrm{M} \mathrm{KCl}$ in $2 \%$ agar and placed in calibration or perfusion solution. For in vivo measurements, the polyethylene $3 \mathrm{M} \mathrm{KCl}$ in $2 \%$ agar bridge was placed in the same Ringer's solution as the cut tail of the rat.

Calcium activity in the perfusion fluids, tubule lumen, and peritubular capillaries was measured with calcium-sensitive microelectrodes $(6,7)$. Micropipettes were pulled from 2-mm o.d. borosilicate glass tubing. The pipettes were beveled (tip 3-4 $\mu \mathrm{m}$ o.d.) and were siliconized with tri- $N$-butylchlorosilane (Pfaltz \& Bauer, Inc.) vapor at $200^{\circ} \mathrm{C}$. The pipettes were backfilled with $100 \mathrm{mM} \mathrm{CaCl}_{2}$ solution and a neutral carrier liquid ion exchanger (IE 200, W-P Instruments) was aspirated through the tip to form a column $300-600 \mu \mathrm{m}$ in length. $\mathrm{Ca}^{2+}$ microelectrodes were connected via $\mathrm{Ag}-\mathrm{AgCl}$ wire to the second channel of the high-impedance electrometer.

Voltage measured with the calcium-sensitive microelectrode in luminal fluid $\left(E_{\mathrm{L}}\right)$ and calibration solutions $\left(E_{\mathrm{C}}\right)$ are given by Nernst equation (9):

$E_{\mathrm{L}}=S \log _{10}\left[\left(a \mathrm{Ca} \mathrm{L}_{\mathrm{L}}\right) /(a \mathrm{Ca})\right]+E_{\mathrm{o}}^{\prime} ;$

$E_{\mathrm{c}}=S \log _{10}\left[\left(a \mathrm{Ca}_{\mathrm{c}}\right) /(a \mathrm{Ca})\right]+E_{\mathrm{o}}^{\prime \prime}$

where $S$ is the slope of the $\mathrm{Ca}^{2+}$ voltage response, $a \mathrm{Ca}_{\mathrm{L}}$ and $a \mathrm{Ca}_{\mathrm{C}}$ are calcium activities in luminal fluid and in one of the calibration solutions, $a \mathrm{Ca}$ is the activity in the solution filling the $\mathrm{Ca}^{2+}$-sensitive microelectrode; $E_{\mathrm{o}}^{\prime}$ and $E_{\mathrm{o}}^{\prime \prime}$ is the sum of the junction potentials and is equal to the voltage measured with a conventional voltage microelectrode. The junction potential in the calibration solutions can be offset to zero by adjusting the $\mathrm{DC}$ position of the electrometer, $E_{0}^{\prime \prime}=0$. This way, the voltage reading with a conventional voltage microelectrode, $E_{\mathrm{o}}^{\prime}=V$, is equal to the change in junction potential, in going from the calibration solutions to the surface of the kidney plus the transepithelial voltage. The difference in junction potential between the calibration solutions and the surface of the kidney is, in part, generated in the circuit going from the reference $3 \mathrm{M} \mathrm{KCl}$ in $2 \%$ agar bridge through the tail and the body of the rat to the surface of the kidney. The difference in junction potentials was in the range $2-10 \mathrm{mV}$ and stayed the same during the course of an experiment. By subtracting Eq. 2 from Eq. 1 and then rearranging, we obtain an equation which was used to calculate $\mathrm{aCa}$ in the tubule lumen:

$a \mathrm{Ca}_{\mathrm{L}}=a \mathrm{Ca}_{\mathrm{c}} \exp _{10}\left[\left(E_{\mathrm{L}}-E_{\mathrm{c}}-V\right) / S\right]$.

Slope of the $\mathrm{Ca}^{2+}$ microelectrode voltage response was calculated from $S=\left(E_{\mathrm{c}}^{\prime}-E_{\mathrm{c}}^{\prime \prime}\right) / \log _{10}\left(a \mathrm{Ca}^{\prime} / a \mathrm{Ca}^{\prime \prime}\right)$,

where $a \mathrm{Ca}^{\prime}$ and $a \mathrm{Ca}^{\prime \prime}$ are calcium activities in two calibration solutions calculated as the product of calcium activity coefficient $\left(\gamma_{\mathrm{Ca}_{\mathrm{a}}}\right)$ and total calcium concentration [Ca], $a \mathrm{Ca}=\gamma_{\mathrm{C}}[\mathrm{Ca}$ ]. Calcium activity coefficients were calculated using the Debye-Hückle (10) equation which for $\mathrm{Ca}$ has the following form:

$-\log _{10} \gamma_{\mathrm{ca}}=2.05 \sqrt{I} /(1+1.98 \sqrt{I})$,

where $I$ is ionic strength (in molar). The $\mathrm{Ca}^{2+}$ microelectrode response slope was linear and averaged $29.0 \pm 0.2 \mathrm{mV} / \log _{10} a \mathrm{Ca}(n=28$ electrodes), ranging from 27.0 to $31.1 \mathrm{mV} / \log _{10} a \mathrm{Ca}$ at $37^{\circ} \mathrm{C}$. Three calibration solutions were used containing $0.1,1.0$, and $10 \mathrm{mM} \mathrm{CaCl}_{2}$ plus $150 \mathrm{mM} \mathrm{NaCl}, \mathrm{pH} 6.02$. Calibration of the microelectrodes were done after one to three measurements using two of the calibration solutions. Measurement of calcium activity in perfusion fluids $\left(a \mathrm{Ca}_{0}\right)$ was determined using the same equations ( 3 and 4), except that $V=0$ because there is no difference in junction potentials in going from the calibration to the perfusion solutions. Free $\mathrm{Ca}$ ion concentration $\left(\mathrm{Ca}^{2+}\right)$ in the perfusion solutions, tubule lumen, and peritubular capillaries was cal- 
culated from $\mathrm{Ca}^{2+}=a \mathrm{Ca} / \gamma_{\mathrm{Ca}}$. The same $\gamma_{\mathrm{Ca}}=0.36$, determined from Debye-Hückel equation, was used for all solutions.

To determine if $\mathrm{pH}$ has an effect on calcium activity and/or $\mathrm{Ca}^{2+}$ microelectrode reading, we varied $\mathrm{pH}$ in solutions containing $1.5 \mathrm{mM}$ $\mathrm{CaCl}_{2}$. As shown in Table II, there was a trend for the voltage reading to be slightly higher at lower $\mathrm{pH}$ but in the range of $\mathrm{pH}$ values used in the present study the effect would be $<5 \%$.

$\mathrm{pH}$ in the perfusion fluids, tubule, and capillary lumen was measured using liquid membrane $\mathrm{pH}$ microelectrodes (11). The electrodes were constructed in the same way as described above for $\mathrm{Ca}^{2+}$ microelectrodes except they were filled with $100 \mathrm{mM} \mathrm{Na}$ citrate- $100 \mathrm{mM}$ $\mathrm{NaCl}, \mathrm{pH} 6.00$, and contained $\mathrm{H}^{+}$-selective liquid in the tip (010 W-P Instruments). $\mathrm{pH}$ in the tubule lumen was determined from the following equation:

$\mathrm{pH}_{\mathrm{L}}=\left({ }^{*} E_{\mathrm{c}}-{ }^{*} E_{\mathrm{L}}+V\right) /{ }^{*} S+\mathrm{pH}_{\mathrm{c}}$

where $\mathrm{pH}_{\mathrm{C}}$ is the known $\mathrm{pH}$ of one of the $\mathrm{pH}$ calibration solutions, ${ }^{*} E_{\mathrm{C}}$ and ${ }^{*} E_{\mathrm{L}}$ are $\mathrm{pH}$ microelectrode voltage readings in one of the calibration solutions and in the luminal fluid, $V$ is the difference in junction potential between the calibration solution and the surface of the kidney measured before and after each experiment with a conventional microelectrode, ${ }^{*} S$ is the slope of the $\mathrm{pH}$ microelectrode calculated from

${ }^{*} S=\left({ }^{*} E^{\prime}-{ }^{*} E^{\prime \prime}\right) /\left(\mathrm{pH}^{\prime \prime}-\mathrm{pH}^{\prime}\right)$,

where $\mathrm{pH}^{\prime \prime}$ and $\mathrm{pH}^{\prime}$ is the known $\mathrm{pH}$ of the calibration solutions and ${ }^{*} E^{\prime \prime}$ and ${ }^{*} E^{\prime}$ are the $\mathrm{pH}$ voltage readings in two calibration solutions. The $\mathrm{pH}$ voltage response was linear in the range $\mathrm{pH} 5-10$ and the slope averaged $63.7 \pm 1.2 \mathrm{mV} / \mathrm{pH}$ units ( $n=8$ electrodes), ranging from 58.1 to $68.0 \mathrm{mV} / \mathrm{pH}$ units at $37^{\circ} \mathrm{C}$. Calibration solutions were prepared by blending Trizma-HCl with Trizma-base. $\mathrm{pH}$ of the perfusion fluids was determined using Eqs. 6 and 7, except there was no difference in junction potentials so that $V=0$. For aCa and $\mathrm{pH}$ measurements in perfusion fluids, solutions were extensively bubbled with $97 \% / 7 \%$ $\mathrm{O}_{2} / \mathrm{CO}_{2}$ gas mixture to achieve $\mathrm{PCO}_{2}$ level present in renal cortex, $\sim 60$ $\mathrm{mmHg}(11)$.

Steady-state voltage, calcium activity, and $\mathrm{pH}$ measurements. The steady-state measurements were carried out using the split oil-droplet method (5). Briefly, a long column of mineral oil was injected into a surface segment of proximal tubule. The mineral oil pipette was withdrawn and the hole created in the tubule wall was large enough to permit the glomerular filtrate to escape; thus the movement of the oil column was prevented. A pipette (3-4- $\mu \mathrm{m}$ tip) containing one of the perfusion fluids was inserted in the middle of the oil column and enough solution was injected to split the oil droplet one surface segment apart. The perfusion pipette was then replaced by an ion-selective or voltage microelectrode. Calcium activity and voltage measurements were made in different tubules of the same kidney. $\mathrm{pH}$ measurements were taken in a different group of animals. Readings were taken after $\sim 5 \mathrm{~min}$ to allow enough time to reach a steady state. For each tubule, to correct the $\mathrm{Ca}$ microelectrode voltage reading for the transepithelial voltage the average $V_{\text {TE }}$ was used in the calculation of stopflow $a \mathrm{Ca}_{\mathrm{L}}$ (Eq. 3). For stop-flow pH measurements, no correction was made because of the small contribution of $V_{\mathrm{TE}}$ to the $\mathrm{pH}$ microelectrode voltage reading. As in the case of the flow experiments, in the

Table II. $\mathrm{Ca}^{2+}$ Microelectrode Measurements in Solutions of Different $\mathrm{pH}$

\begin{tabular}{llllll}
\hline $\mathrm{pH}$ & 4.81 & 6.73 & 7.15 & 7.57 & 8.07 \\
$E_{\mathrm{Ca}^{2+}, m V}$ & 8.8 & 8.5 & 8.3 & 8.1 & 8.2 \\
$a \mathrm{Ca}, m M$ & 0.544 & 0.520 & 0.522 & 0.515 & 0.518
\end{tabular}

Each solution contained $1.5 \mathrm{mM} \mathrm{CaCl}_{2}$ plus $150 \mathrm{mM} \mathrm{NaCl}$. pH was adjusted by blending Trizma-HCl with Trizma-Base buffer (Sigma Chemical Co.). Each value represents a single measurement. stop-flow studies $\mathrm{Ca}$ and $\mathrm{pH}$ microelectrode voltage readings were corrected for the difference in junction potential between the calibration solution and the surface of the kidney.

To avoid the problem of $\mathrm{KCl}$ leakage from $3 \mathrm{M} \mathrm{KCl} / 2 \%$ agar microelectrodes into the small volume of the tubule stationary fluid column, the voltage microelectrodes were filled with the same solution that was injected into the lumen. Using the electrometric titration method (8), we determined that the $3 \mathrm{M} \mathrm{KCl} / 2 \%$ agar microelectrodes leak $2 \times 10^{-11} \mathrm{~mol}$ of chloride per minute. In a droplet of the size of the fluid column used to split the oil droplet $(0.2 \mathrm{nl})$ the leak from the electrode would increase chloride and potassium concentration by 100 $\mathrm{mM}$. In contrast, when tubules are perfused at $20 \mathrm{nl} / \mathrm{min}$, inserting the $3 \mathrm{M} \mathrm{KCl} / 2 \%$ agar electrode would increase the chloride and potassium concentration by only $1.0 \mathrm{mM}$ and thus have no significant effect on $V_{\text {TE }}$.

Calculation of electrochemical driving force. The transepithelial electrochemical gradient $\left(\Delta \tilde{C}_{\mathrm{Ca}_{\mathrm{a}}}\right)$ was calculated as the driving-force term in the Goldman-Hodgkin-Katz equation (9):

$$
\begin{aligned}
& \Delta \tilde{C}_{\mathrm{ca}}=z F V_{\mathrm{TE}} / R T\left[\overline{\mathrm{Ca}}_{\mathrm{L}}{ }^{2+}-\mathrm{Ca}_{\mathrm{P}}{ }^{2+} \exp \left(-z F V_{\mathrm{TE}} / R T\right)\right] / \\
& {\left[1-\exp \left(-z F V_{\mathrm{TE}} / R T\right)\right],}
\end{aligned}
$$

where $z F / R T$ is $0.0748 \mathrm{mV}^{-1}, \mathrm{Ca}_{\mathrm{p}}{ }^{2+}$ is the group average calcium ion concentration in peritubular capillaries, and $\overline{C a}_{\mathbf{L}}{ }^{2+}$ is the logarithmic mean of the calcium ion concentration along the perfused segment calculated by the following (12):

$\overline{C a}_{L}{ }^{2+}=\left(\mathrm{Ca}_{0}{ }^{2+}-\mathrm{Ca}_{\mathrm{L}}{ }^{2+}\right) / \ln \left(\mathrm{Ca}_{0}{ }^{2+} / \mathrm{Ca}_{\mathrm{L}}{ }^{2+}\right)$,

where $\mathrm{Ca}_{0}{ }^{2+}$ and $\mathrm{Ca}_{\mathrm{L}}{ }^{2+}$ is the calcium ion concentration in the perfusion fluid and the group mean concentration at the end of the perfused segment. To calculate the voltage contribution to $\Delta \tilde{C}_{\mathrm{Ca}}$, we used the group mean $V_{\mathrm{TE}}$ at the end of the perfused segment assuming, as was the case with the $\mathrm{HCO}_{3}$ solution (8), that the voltage remained approximately constant along most of the perfused segment.

The results are expressed as means $\pm \mathrm{SE}$; significance of difference between values was assessed by means of a modified $t$ statistics (analysis of variance). Values for the differences were calculated using the Bonferroni method (13). $P<0.05$ determined by the two-tailed test was considered significant.

\section{Results}

Calcium activity averaged $0.384 \pm 0.011 \mathrm{mM}$ (calcium ion concentration $1.07 \pm 0.03 \mathrm{mM}$ ) in 46 peritubular capillaries of nine rats.

The measured values for net fluid transport, total calcium concentration in perfusion and collection fluids, and net calcium fluxes are given in Table III. Results of voltage, calcium activity, and ion concentrations are given in Table IV, and pH in Table V. Because the perfusion solutions contained 26-32 $\mathrm{mM}$ mannitol, net fluid absorption was reduced to near zero with all perfusates (7).

When tubules were perfused with the control Cl-containing solution, solution I, Ca absorption averaged $3.33 \pm 0.65 \mathrm{pmol} /$ $\min (n=45)$ and as result total $\mathrm{Ca}$ concentration along the perfused segment decreased. Although $V_{\mathrm{TE}}$ at the end of the perfused averaged $1.64 \pm 0.19 \mathrm{mV}(n=32)$ (lumen-positive), $\mathrm{Ca}_{\mathrm{L}}{ }^{2+}$ was $1.05 \pm 0.03 \mathrm{mM}(n=44)$, and thus did not fall below the value in the capillaries. The calculated electrochemical gradient with this solution was $0.28 \mathrm{mM}$.

When a portion of the $\mathrm{Cl}(27 \mathrm{mM})$ was replaced with $\mathrm{HCO}_{3}$, solution II, net $\mathrm{Ca}$ absorption more than doubled and averaged $7.13 \pm 0.56 \mathrm{pmol} / \mathrm{min}(n=64)$. Compared to the buffer-free $\mathrm{Cl}$ solution, luminal $\mathrm{HCO}_{3}$ had no measurable effect on net $\mathrm{Na}$ transport; total $\mathrm{Na}$ concentration in the col- 
Table III. Results of Ion Transport Experiments

\begin{tabular}{|c|c|c|c|c|c|}
\hline Solution & & $J_{\mathrm{v}}$ & [Ca]。 & {$[\mathrm{Ca}]_{\mathbf{L}}$} & $J_{\mathbf{a}}$ \\
\hline & $n$ & $\mathrm{nl} / \mathrm{min}$ & $m M$ & $m M$ & $\mathrm{pmol} / \mathrm{min}$ \\
\hline I. $\mathrm{Cl}$ & 45 & $0.12 \pm 0.25$ & $1.47 \pm 0.04$ & $1.30 \pm 0.03$ & $3.33 \pm 0.65$ \\
\hline II. $\mathrm{HCO}_{3}$ & 64 & $0.17 \pm 0.23$ & $1.50 \pm 0.12$ & $1.11 \pm 0.02^{*}$ & $7.13 \pm 0.56^{*}$ \\
\hline III. $\mathrm{HCO}_{3}+\mathrm{ATZ}$ & 18 & $-0.56 \pm 0.17$ & $1.49 \pm 0.04$ & $1.32 \pm 0.04$ & $2.78 \pm 1.08$ \\
\hline IV. $\mathrm{HCO}_{3}+\mathrm{MIA}$ & 8 & $-0.24 \pm 0.43$ & $1.44 \pm 0.03$ & $1.25 \pm 0.04$ & $3.17 \pm 1.36$ \\
\hline V. Hepes & 15 & $-0.18 \pm 0.31$ & $1.44 \pm 0.02$ & $1.24 \pm 0.03$ & $3.48 \pm 0.57$ \\
\hline
\end{tabular}

Values are means \pm SE. $n$ is number of tubules. $J_{v}$, net fluid transport $\left(+\right.$, absorption; - , secretion); $[\mathrm{Ca}]_{\mathrm{o}}$ and $[\mathrm{Ca}]_{\mathrm{L}}$, total calcium concentration in perfused and collected fluids; $J_{\mathrm{ca}}$, net transepithelial calcium transport. Probability of no difference from result with solution I is indicated by * for $P<0.001$ (analysis of variance).

lected fluid and $J_{\mathrm{Na}}$ averaged $142.0 \pm 2.0 \mathrm{mM}$ and $201 \pm 40$ $\mathrm{pmol} / \mathrm{min}(n=19)$ for $\mathrm{HCO}_{3}$, and $142.9 \pm 1.8 \mathrm{mM}$ and $294 \pm 31 \mathrm{pmol} / \mathrm{min}(n=19)$ for the $\mathrm{Cl}$ solution. Therefore, the effect of $\mathrm{HCO}_{3}$ on $\mathrm{Ca}$ transport appears to be dissociated from the net transepithelial $\mathrm{Na}$ flux. With $\mathrm{HCO}_{3}, \mathrm{pH}$ of the perfusion solution was 7.25 and as a result of acidification it fell along the perfused segment to $7.00 \pm 0.03(n=36)$. Compared to $\mathrm{HCO}_{3}$, with $\mathrm{Cl}$ solution, perfusion fluid, 5.34, and luminal $\mathrm{pH}$ at the end of the perfused segment, $6.61 \pm 0.06(n=6)$, were significantly lower (Table $\mathrm{V}$ ). Even though $V_{\mathrm{TE}}$ was less lumen-positive, $0.78 \pm 0.16 \mathrm{mV}(n=17)$, calcium ion concentration along the perfused segment fell significantly below the value in the capillary and averaged $0.88 \pm 0.03 \mathrm{mM}(n=32)(P$ $<0.001$ compared with capillary). Because with $\mathrm{HCO}_{3}$ solution $\Delta \tilde{C}_{\mathrm{Ca}}$ was only $0.03 \mathrm{mM}$, the enhanced calcium absorption could not be accounted for by the electrochemical gradient.

To determine whether the enhanced $\mathrm{Ca}$ absorption with the $\mathrm{HCO}_{3}$ containing solution was the result of $\mathrm{HCO}_{3}$ absorption or the presence of luminal $\mathrm{HCO}_{3}$ per se, we next perfused tubules with $\mathrm{HCO}_{3}$ solution which contained $1.0 \mathrm{mM}$ carbonic anhydrase inhibitor acetazolamide (ATZ), ${ }^{1}$ solution III. ATZ has a high cell permeability and inhibits both luminal and cellular carbonic anhydrase (14). With ATZ, luminal pH averaged $6.87 \pm 0.06(n=16)$, a value that is not statistically different from the group mean of all tubules perfused with $\mathrm{HCO}_{3}$ perfusate $(P<0.1$, analysis of variance). However, when we compare $\mathrm{pH}_{\mathrm{L}}$ with $\mathrm{ATZ}, 6.87 \pm 0.06$, to the values obtained in the same kidney with the $\mathrm{HCO}_{3}$ solution, $6.94 \pm 0.05$, the results are statistically different $(P<0.001$, $n=16$ ). This is consistent with our previous study in which we also showed that ATZ lowers luminal pH (8). Results in the present study are similar to the $\mathrm{pH}$ values of 6.95 for $\mathrm{HCO}_{3}$ and 6.84 for $\mathrm{HCO}_{3}+\mathrm{ATZ}$ solution obtained by Lucci et al. (14) who measured four surface segments from the perfusion site. These results were not statistically different but with $10^{-4}$ benzolamide (carbonic anhydrase inhibitor with a low cell permeability) luminal $\mathrm{pH}$ was significantly lower (14). In their study both drugs inhibited $\mathrm{HCO}_{3}$ absorption equally, $>90 \%$. We have previously found that $\mathrm{ATZ}$ decreased $\mathrm{HCO}_{3}$ absorption from 224 to $67 \mathrm{pmol} / \mathrm{min}$ and increased luminal $\mathrm{HCO}_{3}$ concentration from 16.4 to $25.0 \mathrm{mM}(8)$. Therefore, in a flow situation, ATZ does not prevent the establishment of a transepithelial $\mathrm{H}^{+}$gradient, but by inhibiting luminal carbonic an-

1. Abbreviations used in this paper: ATZ, acetazolamide; MIA, 5- $(N$ methyl- $N$-isobutyl)-amiloride. hydrase it prevents the catalized buffering of secreted protons by the $\mathrm{HCO}_{3} / \mathrm{CO}_{2}$ system. As a result, $\mathrm{HCO}_{3}$ absorption and the total amount of acid secreted are inhibited.

As shown in Table III, with ATZ, calcium absorption averaged $2.78 \pm 1.08 \mathrm{pmol} / \mathrm{min}(n=18)$, not different from the control. Compared to control, solution $\mathrm{I}, \mathrm{Ca}_{\mathrm{L}}{ }^{2+}$ was not different, averaging $1.11 \pm 0.05 \mathrm{mM}(n=17)$, but because $V_{\mathrm{TE}}$ was lower, $0.31 \pm 0.19 \mathrm{mV}(n=17)$, the electrochemical driving force was likewise lower, $0.14 \mathrm{mM}$. The ATZ results suggest that the stimulation of $\mathrm{Ca}$ absorption with $\mathrm{HCO}_{3}$ was likely the result of acidification-mediated $\mathrm{HCO}_{3}$ absorption and not due to the presence of luminal $\mathrm{HCO}_{3}$ per se.

To further test if the stimulation of $\mathrm{Ca}$ absorption is linked to acidification, we perfused tubules with $\mathrm{HCO}_{3}$ solution containing $10^{-5} \mathrm{M}$ of an amiloride analogue 5-( $N$-methyl- $N$-isobutyl)-amiloride (MIA), an inhibitor of $\mathrm{Na} / \mathrm{H}$ exchange (15). With MIA there was no acidification of tubule fluid and luminal $\mathrm{pH}$ at the end of the perfused segment was significantly higher compared with $\mathrm{HCO}_{3}$ solution, averaging 7.24 0.04 ( $n$ $=11$ ) (Table V). These results are consistent with the study by Howlin et al. (16) who showed that amiloride inhibits $\mathrm{HCO}_{3}$ absorption. With MIA net Ca absorption averaged 3.17 \pm 1.36 $\mathrm{pmol} / \mathrm{min}(n=8)$, a rate that was not different from the control buffer-free $\mathrm{Cl}$ containing solution. With this perfusate $\mathrm{Ca}_{\mathrm{L}}{ }^{2+}$ averaged $0.99 \pm 0.05 \mathrm{mM}(n=7), V_{\mathrm{TE}} 0.70 \pm 0.20 \mathrm{mV}(n$ $=5$ ), and $\Delta \tilde{C}_{\mathrm{Ca}}$ was $0.08 \mathrm{mM}$. Because amiloride inhibited proximal acidification this result would further support the notion that acidification of tubule fluid with the $\mathrm{HCO}_{3}$ perfusate stimulated $\mathrm{Ca}$ absorption.

If the enhanced $\mathrm{Ca}$ absorption was the result of proton secretion by the proximal tubule, then other buffers with $\mathrm{pKa}$ similar to that for $\mathrm{HCO}_{3} / \mathrm{CO}_{2}$ should show the same effect. To test this hypothesis, tubules were perfused with solution containing $27 \mathrm{mM}$ Hepes ( $\mathrm{pKa}=7.5$ solution $\mathrm{V}$ ). As in the case with $\mathrm{HCO}_{3}$, with Hepes solution there was acidification of perfusate along the tubule but compared with $\mathrm{HCO}_{3}$ the perfusion fluid, 7.09, and luminal $\mathrm{pH}$ at the end of perfused segment, $6.81 \pm 0.06(n=11)$, were lower. Under the same conditions, we have previously found that with the same Hepes perfusate, there was significant accumulation of $\mathrm{HCO}_{3}$ in the lumen, $J_{\mathrm{HCO}_{3}}=-317 \mathrm{pmol} / \mathrm{min}$ (17). With Hepes in the perfusate net $\mathrm{Ca}$ absorption averaged $3.48 \pm 0.57 \mathrm{pmol} / \mathrm{min}$ ( $n$ $=15$ ) which was not different from the control buffer-free solution, but the transepithelial electrochemical driving force was close to zero due to the fact that both $\mathrm{Ca}_{\mathrm{L}}{ }^{2+}$ and $V_{\mathrm{TE}}$ were significantly lower, $0.88 \pm 0.03 \mathrm{mM}(n=18)$ and $0.61 \pm 0.40$ $\mathrm{mV}(n=13)$, respectively. 
Table IV. Results of Voltage, Calcium Activity, and Calcium Ion Concentration

\begin{tabular}{|c|c|c|c|c|c|c|}
\hline Solution & $a \mathrm{Ca}_{0}$ & $\mathrm{Ca}_{0}^{2+}$ & $a C a_{L}$ & $\mathrm{CaL}_{\mathrm{L}}^{2+}$ & $V_{\mathrm{TE}}$ & $\Delta \tilde{C}_{\mathrm{c}}$ \\
\hline & $m M$ & $m M$ & $m M$ & $m M$ & $m V$ & $m M$ \\
\hline I. $\mathrm{Cl}$ & 0.511 & 1.42 & $\begin{array}{c}0.378 \pm 0.011 \\
(44)\end{array}$ & $\begin{array}{c}1.05 \pm 0.03 \\
(44)\end{array}$ & $\begin{array}{c}1.64 \pm 0.19 \\
(32)\end{array}$ & 0.28 \\
\hline II. $\mathrm{HCO}_{3}$ & 0.439 & 1.22 & $\begin{array}{c}0.317 \pm 0.011^{*} \\
(32)\end{array}$ & $\begin{array}{c}0.88 \pm 0.03^{*} \\
\quad(32)\end{array}$ & $\begin{array}{c}0.78 \pm 0.16^{\ddagger} \\
(17)\end{array}$ & 0.03 \\
\hline III. $\mathrm{HCO}_{3}+\mathrm{ATZ}$ & 0.439 & 1.22 & $\begin{array}{c}0.398 \pm 0.016 \\
(17)\end{array}$ & $\begin{array}{c}1.11 \pm 0.05 \\
(17)\end{array}$ & $\begin{array}{c}0.31 \pm 0.19^{*} \\
\quad(17)\end{array}$ & 0.13 \\
\hline IV. $\mathrm{HCO}_{3}+\mathrm{MIA}$ & 0.439 & 1.22 & $\begin{array}{c}0.357 \pm 0.018 \\
(7)\end{array}$ & $\begin{array}{c}0.99 \pm 0.05 \\
(7)\end{array}$ & $\begin{array}{c}0.70 \pm 0.20 \\
(5)\end{array}$ & 0.08 \\
\hline V. Hepes & 0.454 & 1.26 & $\begin{array}{c}0.317 \pm 0.012^{*} \\
(18)\end{array}$ & $\begin{array}{c}0.88 \pm 0.03^{*} \\
(18)\end{array}$ & $\begin{array}{c}0.61 \pm 0.40^{\ddagger} \\
\quad(13)\end{array}$ & 0.04 \\
\hline
\end{tabular}

Values are means $\pm \mathrm{SE}$. Numbers in parentheses are numbers of tubules. $a \mathrm{Ca} \mathrm{a}_{\mathrm{O}}$ and $a \mathrm{Ca}_{\mathrm{L}}$, calcium activity in perfused and luminal fluids measured with calcium sensitive microelectrodes. $\mathrm{Ca}_{0}^{2+}$ and $\mathrm{Ca}_{\mathrm{L}}^{2+}$ are free ionic calcium concentrations calculated from calcium activity using actively coefficient 0.36 (Debye-Hückel equation). $V_{\mathrm{TE}}$, transepithelial voltage (lumen relative to interstitium) $\Delta \tilde{C}_{\mathrm{Ca}}$; electrochemical gradient calculated using free calcium ion concentration and $\mathrm{V}_{\mathrm{TE}}$ (see Methods). For measurements of $\mathrm{Ca}^{2+}$ in perfusion fluids, solutions were extensively gassed with $93 \% / 7 \% \mathrm{O}_{2} / \mathrm{CO}_{2}$ gas mixture. Probability of no difference from results with solution I as indicated by ${ }^{*}$ for $P<0.005$ and ${ }^{\star}$ for $P$ $<0.05$ (analysis of variance).

Because with solution II, the $\mathrm{HCO}_{3}$-stimulated calcium absorption occurred despite a decrease in $\Delta \tilde{C}_{\mathrm{Ca}}$, the results indicate that $\mathrm{HCO}_{3}$ absorption mediates this effect via an active transport process. To confirm this, we carried out split-oil steady-state measurements of calcium ion concentration and voltage. When $\mathrm{HCO}_{3}$ solution was injected, the steady-state $\mathrm{Ca}_{\mathrm{L}}{ }^{2+}$ averaged $0.86 \pm 0.03 \mathrm{mM}\left(a \mathrm{Ca}_{\mathrm{L}}=0.310 \pm 0.012\right)(n=8)$ and $V_{\mathrm{TE}} 0.50 \pm 0.20 \mathrm{mV}(n=4)$. In the absence of active transport process for the same transepithelial calcium ion concentration gradient to develop, we estimate, using the Nernst equation, $V_{\mathrm{TE}}=R T / \mathrm{zF} \ln \left(\mathrm{Ca}_{\mathrm{P}}{ }^{2+} / \mathrm{Ca}_{\mathrm{L}}{ }^{2+}\right)$, that the equilibrium $V_{\mathrm{TE}}$ would have to be around $2.9 \mathrm{mV}$. Because the calculated $V_{\mathrm{TE}}$ is higher than the measured value the results suggest active transport component. With ATZ, solution III, the steady-state $\mathrm{Ca}_{\mathrm{L}}{ }^{2+}$ significantly increased and was not different from the value in the capillaries, $1.06 \pm 0.03(n=8)$ vs. $1.07(a \mathrm{Ca}$; $0.382 \pm 0.011$ vs. $0.384 \mathrm{mM}$ ). This increase cannot be accounted for by $V_{\mathrm{TE}}$ which remained unchanged, $0.60 \pm 0.21$ $\mathrm{mV}(n=4)$. With $\mathrm{HCO}_{3}$, the stop-flow luminal $\mathrm{pH}$ averaged $6.95 \pm 0.03(n=17)$, but in contrast to the flow studies, with $\mathrm{HCO}_{3}+\mathrm{ATZ}$, luminal $\mathrm{pH}$ of the stationary fluid column was higher 7.14 $\pm 0.04(n=17)(P<0.001)$. The increase in stop-

Table V. Results of pH Measurements

\begin{tabular}{cccccc}
\hline Solution & $\begin{array}{c}\mathrm{I} \\
\mathrm{Cl}\end{array}$ & $\begin{array}{c}\mathrm{II} \\
\mathrm{HCO}_{3}\end{array}$ & $\begin{array}{c}\mathrm{III} \\
\mathrm{HCO}_{3}+\mathrm{ATZ}\end{array}$ & $\begin{array}{c}\mathrm{IV} \\
\mathrm{HCO}_{3}+\mathrm{MIA}\end{array}$ & $\begin{array}{c}\mathrm{V} \\
\text { Hepes }\end{array}$ \\
\hline $\mathrm{pH}_{\mathrm{o}}$ & 5.34 & 7.25 & 7.25 & 7.25 & 7.09 \\
$\mathrm{pH}_{\mathrm{L}}$ & $6.61^{*}$ & 7.00 & 6.87 & $7.24^{*}$ & $6.81^{\ddagger}$ \\
& \pm 0.06 & \pm 0.03 & \pm 0.06 & \pm 0.04 & \pm 0.06 \\
& $(6)$ & $(36)$ & $(16)$ & $(11)$ & $(11)$
\end{tabular}

Values are means $\pm \mathrm{SE}$. Numbers in parentheses are number of tubules. $\mathrm{pH}_{\mathrm{o}}$ and $\mathrm{pH}_{\mathrm{L}}$ were measured in perfusion solutions and tubule lumen using $\mathrm{pH}$ sensitive microelectrodes.

For $\mathrm{pH}$ measurements in perfusion fluids, solutions were extensively bubbled with $93 \% / 7 \% \mathrm{O}_{2} / \mathrm{CO}_{2}$ gas mixture $\left(\mathrm{PCO}_{2}=61.9 \mathrm{mmHg}\right.$, blood gas analyzer, ABL-1, Radiometer, Copenhagen).

Probability of no difference from results with solution II as indicated for ${ }^{*}$ for $P<0.001$ and ${ }^{\ddagger}$ for $P<0.02$ (analysis of variance). flow $\mathrm{pH}_{\mathrm{L}}$ is likely the result of inhibition of cellular carbonic anhydrase involved in $\mathrm{H}^{+}$secretion (14). Because ATZ increased the stop-flow luminal calcium ion concentration, the results confirm presence of active calcium transport process, and because the increase in $\mathrm{Ca}^{2+}$ was associated with increased luminal $\mathrm{pH}$, the results also suggest that active $\mathrm{Ca}$ absorption may be linked to acidification.

\section{Discussion}

In the absence of net water movement, calcium transport by the proximal tubule is determined by the electrochemical driving forces and active transport (6). To evaluate the contribution of the transepithelial electrochemical gradient to the $\mathrm{HCO}_{3}$ stimulated $\mathrm{Ca}$ absorption, we measured transepithelial voltage and calcium ion concentration in tubule fluid and in the peritubular capillary blood. Compared to the buffer-free control solution, with $\mathrm{HCO}_{3}$ in the perfusate, $V_{\mathrm{TE}}$ and $\mathrm{Ca}_{\mathrm{L}}{ }^{2+}$ were significantly reduced and as a result $\Delta \tilde{C}_{\mathrm{Ca}}$ was also reduced (Table IV). Because the enhanced $\mathrm{Ca}$ absorption occurred despite a decrease in the electrochemical driving force, the results indicate that $\mathrm{HCO}_{3}$ stimulated an active $\mathrm{Ca}$ transport process.

In contrast to our observation, Sutton et al. (2) found that in dogs, relative to $\mathrm{Na}$ reabsorption, intravenous infusion of $\mathrm{HCO}_{3}$ had no effect on proximal Ca reabsorption (2). The results showed that $\mathrm{HCO}_{3}$ administration decreased urinary $\mathrm{Ca}$ excretion by a direct tubule effect beyond the late proximal tubule. In the study of Sutton et al. (2), the three groups of animals that received infusion of $\mathrm{HCO}_{3}$ (metabolic acidosis, intact and thyroparathyroidectomized dogs) had a decrease in proximal fluid reabsorption and a decrease in ultrafiltrable $\mathrm{Ca}$. It is possible, that because these changes would inhibit $\mathrm{Ca}$ reabsorption, the direct tubule effect of $\mathrm{HCO}_{3}$ was not observed. In our study, we directly examined the effect of luminal $\mathrm{HCO}_{3}$, while keeping net water movement near zero for all perfusates and taking into account the contribution of the electrochemical driving forces.

Ullrich et al. (5) using the stop-flow microperfusion technique with simultaneous capillary perfusion demonstrated ac- 
tive calcium absorption, but in contrast to our study, it was not affected by $\mathrm{HCO}_{3}$. There are at least two possible explanations for the discrepancy: (a) In the Ullrich study $V_{\mathrm{TE}}$ was not measured directly but was estimated from the $\mathrm{Cl}$ gradient across the tubule wall using the Nernst equation. With $\mathrm{HCO}_{3}$ the luminal $\mathrm{Ca}$ concentration was $0.32 \mathrm{mM}$ lower than in the capillary, a difference that diminished to $0.19 \mathrm{mM}$ with bufferfree solution. Because the electrochemical gradient did not change, the authors concluded that this fall was the result of a less lumen positive $V_{\mathrm{TE}}$. This conclusion may not be correct, because $\mathrm{Cl}$ transport by the proximal tubule is not all passive (8) and thus the calculated $V_{\mathrm{TE}}$ may not be an accurate estimate of the true $V_{\mathrm{TE}}$. (b) In the Ullrich study the steady-state $\mathrm{Ca}$ ion concentration was not determined directly but was measured as ${ }^{45} \mathrm{Ca}$ counts. In $\mathrm{HCO}_{3}$-containing solutions, $\mathrm{HCO}_{3}-\mathrm{Ca}_{2+}$ soluble complexes (see $\mathrm{Ca}_{0}{ }^{2+}$, Table IV) (6) decrease calcium ion concentration; thus, using the ${ }^{45} \mathrm{Ca}$ radioactivity to calculate $\mathrm{Ca}^{2+}$ concentration gradient may not be appropriate.

To determine if, in our study, the $\mathrm{HCO}_{3}$-stimulated calcium absorption was the result of luminal $\mathrm{HCO}_{3}$ per se or the result of $\mathrm{HCO}_{3}$ absorption, we perfused tubules with $\mathrm{HCO}_{3}$ containing solution which also contained $10^{-3} \mathrm{M}$ ATZ. With this perfusate, $J_{\mathrm{Ca}}$ was not different from the buffer-free control solution. Because ATZ inhibited $\mathrm{HCO}_{3}$ absorption and increased luminal $\mathrm{HCO}_{3}$ concentration (8), this result suggests that the enhanced active $\mathrm{Ca}$ absorption could not be accounted for by luminal $\mathrm{HCO}_{3}$ per se but would be more likely the result of acidification-mediated $\mathrm{HCO}_{3}$ absorption. Ullrich et al. (5) in the stop-flow microperfusion study also found that ATZ decreased $\mathrm{Ca}$ concentration gradient, a change which was attributed to $V_{\mathrm{TE}}$ rather than to active transport. Because $V_{\mathrm{TE}}$ determined from $\mathrm{Cl}$ concentration gradient may not be accurate, it is possible that the decreased $\mathrm{Ca}$ concentration gradient with ATZ in the study by Ullrich et al. (5) was, as in our case, the result of a decrease in active $\mathrm{Ca}$ transport. To elucidate the apparent discrepancy between the two studies on the effects of ATZ we performed similar stop-flow study and directly measured luminal $\mathrm{Ca}$ activity, $\mathrm{pH}$ and $V_{\mathrm{TE}}$. We found that ATZ did not have a measurable effect on $V_{\mathrm{TE}}$ and yet decreased the transepithelial $\mathrm{Ca}^{2+}$ gradient from 0.29 to $0.01 \mathrm{mM}$. These data provide further evidence for ATZ-inhibitable active calcium absorption. Because in the stop-flow situation the increase in luminal $\mathrm{Ca}^{2+}$ concentration induced by ATZ was associated with an increase in luminal $\mathrm{pH}$ the data also suggest that active $\mathrm{Ca}^{2+}$ transport may be linked to acidification of proximal tubule fluid. Although a direct effect of luminal $\mathrm{pH}$ on $a \mathrm{Ca}_{\mathrm{L}}$ or $\mathrm{Ca}$ transport can not be ruled out, no differences in $a \mathrm{Ca}_{\mathrm{L}}$ or $\mathrm{J}_{\mathrm{Ca}}$ were observed between control $\mathrm{Cl}, \mathrm{HCO}_{3}+\mathrm{ATZ}$, or $\mathrm{HCO}_{3}+$ MIA solutions (Tables III and IV) even though the $\mathrm{pH}_{\mathrm{L}}$ were different; $6.61,6.87$, and 7.24 , respectively (Table V).

To further test the possibility that the enhanced $\mathrm{Ca}$ absorption is the result of acidification-mediated $\mathrm{HCO}_{3}$ absorption, we perfused the tubules with $\mathrm{HCO}_{3}$ solution that in addition contained $\mathrm{Na} / \mathrm{H}$ exchange inhibitor, MIA. Because MIA inhibited luminal fluid acidification and $\mathrm{Ca}^{2+}$ absorption, the data support the notion that acidification of luminal fluid stimulates proximal active $\mathrm{Ca}^{2+}$ absorption.

When tubules were perfused with Hepes solution the rates of $\mathrm{Ca}$ transport were not different from the buffer-free control solution but $V_{\mathrm{TE}}$ was significantly less lumen-positive. We and others have shown that $V_{\mathrm{TE}}$ is an important driving force of $\mathrm{Ca}$ transport by the proximal tubule $(6,18,19)$. Thus, based on the voltage change, we would predict that with Hepes, $\mathrm{Ca}$ absorption should have diminished when in fact there was no change. This result suggests to us, that as with $\mathrm{HCO}_{3}$, acidification of Hepes containing tubule fluid resulted in stimulation of active $\mathrm{Ca}$ absorption. In Fig. 1 we plotted $J_{\mathrm{Ca}}$ against $\Delta \tilde{C}_{\mathrm{Ca}}$ for each of the perfusates. The dashed line is based on our previous study that showed a nearly linear relationship between net calcium flux and the electrochemical driving forces (6) and was drawn here through the origin. In the absence of active transport one would predict that the points should fall on or near the line. It is apparent that both $\mathrm{HCO}_{3}$ and Hepes points are well above the line indicating a component of active absorption. With both of the solutions the predicted $J_{\mathrm{Ca}}$ should be $<1 \mathrm{pmol} / \mathrm{min}$ or only $14 \%$ of the measured value for the $\mathrm{HCO}_{3}$ perfusate and $30 \%$ of the measured value for Hepes. However, it is also apparent that the rate of $\mathrm{Ca}$ absorption with $\mathrm{HCO}_{3}$ is twice as much as with Hepes, even though $\Delta \tilde{C}_{\mathrm{Ca}}$ are close. The reason for this is unclear but at least two explanations seem possible. First, with $\mathrm{HCO}_{3}$ and Hepes there was acidification of tubule fluid along the perfused segment but both the perfusion and luminal fluid $\mathrm{pH}$ was lower with Hepes (Table V). With a lower luminal fluid $\mathrm{pH}$ the rate of proton secretion may also be lower (20) and if $\mathrm{Ca}^{2+}$ transport is linked to acidification then the rates of $\mathrm{Ca}^{2+}$ absorption would also be lower. Secondly, with Hepes as a result of intraluminal generation and backflux, $\mathrm{HCO}_{3}$ accumulates in the tubule lumen (16). $\mathrm{HCO}_{3}$ backflux into the lumen may bring $\mathrm{Ca}^{2+}$ ions with it by virtue of soluble ion complex formation and thus decrease the net rate of $\mathrm{Ca}^{2+}$ absorption. Secretion of $\mathrm{HCO}_{3}-\mathrm{Ca}^{2+}$ may also account for the fact that in Fig. 1 the point for buffer-free control solution appears to fall below the dashed line (i.e., more $\mathrm{Ca}^{2+}$ ions present in the lumen than can be accounted for by $\left.\Delta \tilde{C}_{\mathrm{Ca}}\right)$.

In this study we present evidence for active $\mathrm{Ca}$ absorption that may be linked to acidification of luminal fluid by the

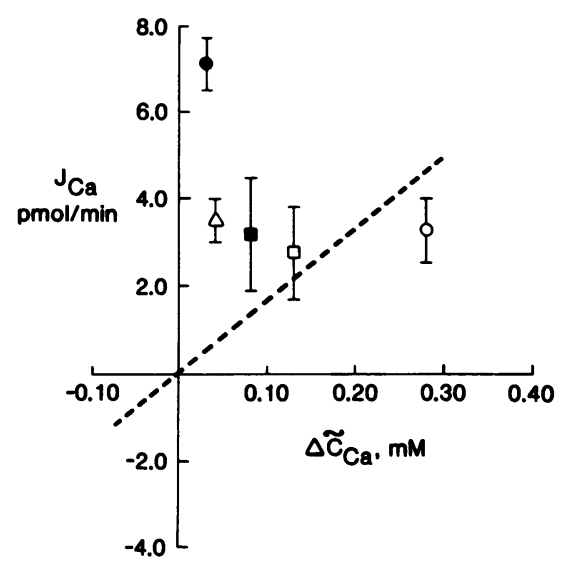

Figure 1. Net calcium fluxes $\left(J_{\mathrm{Ca}}\right)$ (Table III) plotted against transepithelial electrochemical concentration difference, $\left(\Delta \tilde{C}_{\mathrm{Ca}_{a}}\right)$ (Table IV). (o) Control, buffer-free solution, solution I; (॰) $\mathrm{HCO}_{3}$, solution II; () $\mathrm{HCO}_{3}+$ ATZ, solution III; (a) $\mathrm{HCO}_{3}+$ MIA, solution IV; ( $\Delta$ ) Hepes, solution V. The dashed line was drawn through the origin and represents the linear relationship that would exist between $\mathrm{Ca}$ flux and the electrochemical driving forces in the rat proximal tubule in absence of any active transport process (6). The slope of this line is $16.4 \mathrm{nl} / \mathrm{min}$ and was calculated as the product of calcium permeability of these tubules, $16.1 \times 10^{-7} \mathrm{~cm}^{2} / \mathrm{s}(6)$, and the averaged perfused length in these experiments, $1.8 \pm 0.1 \mathrm{~mm}(n=129)$. 
proximal tubule cell. It is thought that because intracellular $\mathrm{Ca}$ ion concentration is $10^{-7} \mathrm{M}$ and because cell membrane potential is negative, there exist a very high electrochemical gradient for passive $\mathrm{Ca}$ entry across the luminal membrane into the cell (21). Calcium is then actively transported across the basolateral membrane against similar but oppositely oriented electrochemical gradient. Studies with basolateral membrane vesicles from rat cortex showed that active calcium transport across this membrane can proceed via ATP-driven Ca pump or $\mathrm{Na}$ gradient driven $\mathrm{Na} / \mathrm{Ca}$ exchange (22). The $\mathrm{Na} / \mathrm{Ca}$ exchange process depends on basolateral $\mathrm{Na} / \mathrm{K}$ ATPase which sets up the $\mathrm{Na}$ gradient. Therefore, it is possible that some of the effects we observed were the result of changes in intracellular $\mathrm{Na}$ concentration. In a system where $\mathrm{Na} / \mathrm{Ca}$ exchange is the major process moving $\mathrm{Ca}^{2+}$ out of the cell, maneuvers that increase cell $\mathrm{Na}$ would lead to a decrease in $\mathrm{Na}^{+}$-driven $\mathrm{Ca}^{2+}$ efflux. That could be the case with ATZ or MIA which may inhibit Na-K-ATPase resulting in increased cell $\mathrm{Na}^{+}$and thus lead to decreased $\mathrm{Ca}^{2+}$ absorption. Even though net transepithelial $\mathrm{Na}$ transport with $\mathrm{HCO}_{3}$ compared to $\mathrm{Cl}$ solution was not different, we can not rule out differences in cell $\mathrm{Na}^{+}$. With $\mathrm{HCO}_{3}, V_{\text {TE }}$ was less lumen-positive, suggesting that with this perfusate, compared to $\mathrm{Cl}$ solution, a larger fraction of net $\mathrm{Na}$ flux was active and transcellular. This would correspond to a situation of increased $\mathrm{Na}$ pumping across the basolateral membrane leading to decreased cell $\mathrm{Na}^{+}$concentration. A fall in intracellular $\mathrm{Na}^{+}$would enhance $\mathrm{Na} / \mathrm{Ca}$ exchange-mediated $\mathrm{Ca}^{2+}$ pumping across the basolateral membrane, a situation that may be present with $\mathrm{HCO}_{3}$ absorption.

Basolateral $\mathrm{Ca}^{2+}$-ATPase is another process that potentially might mediate transcellular $\mathrm{Ca}$ transport, a process that may be affected by intracellular $\mathrm{pH}$ and possibly account for our findings. A recent study suggested that in reconstituted erythrocytes, electrogenic $\mathrm{Ca}^{2+}$-translocating ATPase not only translocates $\mathrm{Ca}^{2+}$ but also transports $\mathrm{H}^{+}$in the opposite direction (23). If present in the basolateral membrane of the proximal tubule cell, such a process may explain our observations because transport of $\mathrm{H}^{+}$by the ATPase into the cell down the electrochemical gradient would add energy for the uphill $\mathrm{Ca}^{2+}$ pumping. There may be other possibilities for our observations but the true explanation may have to be derived from direct measurements of intracellular $\mathrm{pH}$ and $\mathrm{Ca}^{2+}$ in proximal tubule cells studied under the condition of the present study.

In summary, we found that luminal $\mathrm{HCO}_{3}$ stimulates active calcium absorption by the rat proximal tubule, a process that may result from acidification-mediated $\mathrm{HCO}_{3}$ absorption. The enhanced $\mathrm{Ca}$ absorption may account, at least in part, for the observation that $\mathrm{HCO}_{3}$ administration lowers renal calcium excretion.

\section{Acknowledgments}

This research was supported by grant R23 DK37316 from the National Institutes of Health, Grant-in-Aid 85689 from the American Heart Association with funds contributed in part by the American Heart Association, Washington Affiliate, and the Northwest Kidney Foundation.

\section{References}

1. Peraino, R. A., W. N. Suki, and B. J. Stinebaugh. 1980. Renal excretion of calcium and magnesium during correction of metabolic acidosis by bicarbonate infusion in dog. Miner. Electrolyte Metab. 3:87-93.

2. Sutton, R. A. L., N. L. M. Wong, and J. H. Dirks. 1979. Effects of metabolic acidosis and alkalosis on sodium and calcium transport in the dog kidney. Kidney Int. 15:520-533.

3. Peraino, R. A., and W. N. Suki. 1980. Urine $\mathrm{HCO}_{3}$ augments renal $\mathrm{Ca}^{2+}$ absorption independent of systemic acid-base changes. $\mathrm{Am}$. J. Physiol. 238 (Renal Fluid Electrolyte Physiol. 7):F393-F398.

4. Goulding, A., and D. Campbell. 1984. Hypocalciuric effects of hydrochlorothiazide in the rat during $\mathrm{NaHCO}_{3}, \mathrm{NaCl}$ and $\mathrm{NH}_{4} \mathrm{Cl}$ loading. Renal Physiol. 7:185-191.

5. Ullrich, K. J., G. Rumrich, and S. Kloss. 1976. Active $\mathrm{Ca}^{2+}$ reabsorption in the proximal tubule of the rat kidney. Pflügers Arch. 364:223-228.

6. Bomsztyk, K., J. P. George, and F. S. Wright. 1984. Effects of luminal fluid anions on calcium transport by proximal tubule. Am.J. Physiol. 246 (Renal Fluid Electrolyte Physiol. 15):F600-F608.

7. Bomsztyk, K., and F. S. Wright. 1986. Dependence of ion fluxes on fluid transport by rat proximal tubule. Am. J. Physiol. 250 (Renal Fluid Electrolyte Physiol. 19):F680-F689.

8. Bomsztyk, K. 1986. Chloride transport by the proximal tubule: effects of bicarbonate absorption. Am. J. Physiol. 250 (Renal fluid Electrolyte Physiol. 19):F1046-F1054.

9. Schultz, S. C. 1980. Basic Principles of Membrane Transport. IUBAB Biophysics Series. Cambridge University Press, Cambridge. 24-30.

10. MacInnes, D. A. 1961. Principles of Electrochemistry. Dover Publications, Inc., New York.

11. Bomsztyk, K., and M. B. Calalb. 1986. A new microelectrode method for simultaneous measurement of $\mathrm{pH}$ and $\mathrm{pCO}_{2}$. Am. J. Physiol. 251 (Renal Fluid Electrolyte Physiol. 20):F933-F937.

12. Riggs, D. S. 1963. The Mathematical Approach to Physiological Problems. Williams \& Wilkins Company, Baltimore. 161-163.

13. Wallestein, S., C. L. Zucker, and J. L. Fleiss. 1980. Some statistical methods in circulation research. Circ. Res. 47:1-9.

14. Lucci, M. S., L. R. Pucacco, T. D. Dubose, J. P. Kokko, and N. W. Carter. 1980. Direct evaluation of acidification by rat proximal tubule: role of carbonic anhydrase. Am. J. Physiol. 238 (Renal Fluid Electrolyte Physiol. 7):F732-F379.

15. Calalb, M. B., T. H. Stanton, L. Smith, E. J. Cragoe, Jr., and K. Bomsztyk. 1987. Recombinant human Interleukin 1-stimulated $\mathrm{Na}+/ \mathrm{H}+$ exchange is not required for differentiation in pre-B lymphocyte cell line, 70Z/3. J. Biol. Chem. 262:3680-36894.

16. Howlin, K. J., B. J. Alpern, and F. C. Rector. 1985. Amiloride inhibition of proximal acidification. Am. J. Physiol. 248 (Renal Fluid Electrolyte Physiol. 17):F773-F778.

17. Bomsztyk, K., E. R. Swenson, and M. B. Calalb. 1987. $\mathrm{HCO}_{3}$ accumulation in proximal tubule: roles of carbonic anhydrase, luminal buffers, and pH. Am. J. Physiol. 252 (Renal Fluid Electrolyte Physiol. 21):F501-F508.

18. Bourdeau, J. E. 1986. Calcium transport across the pars recta of cortical segment 2 proximal tubules. Am. J. Physiol. 251 (Renal Fluid Electrolyte Physiol. 20):F718-F724.

19. Ng, R. C. K., D. Rouse, and W. N. Suki. 1984. Calcium transport in the rabbit superficial proximal convoluted tubule. J. Clin. Invest. 74:834-842.

20. Chan, Y. L., G. Malnic, and G. Giebish. 1983. Passive driving forces of proximal tubular fluid and bicarbonate transport: gradient dependence of $\mathrm{H}^{+}$secretion. Am. J. Physiol. 245 (Renal Fluid Electrolyte Physiol. 14):F622-F633.

21. Suki, W. N. 1979. Calcium transport in the nephron. Am. J. Physiol. 237 (Renal Fluid Electrolyte Physiol. 6):F1-F6.

22. Gmaj, P. G. H., H. Murer and R. Kinne. 1979. Calcium ion transport across plasma membranes isolated from rat kidney cortex. Biochem. J. 178:549-557.

23. Villalobo, A. and B. D. Roufogalis. 1986. Proton counter transport by reconstituted erythrocyte $\mathrm{Ca}^{2+}$-translocating ATPase: evidence using ionophoretic compounds. J. Membr. Biol. 93:249-258. 